\title{
BIOINDIKATOR KUALITAS PERAIRAN SUNGAI
}

\author{
Ariane Pratiwi
Jurusan Teknik Lingkungan, Fakultas Arsitektur Lanskap dan Teknologi Lingkungan, Universitas Trisakti, Jakarta, Indonesia

Email korespondensi: ariane08215008@trisakti.ac.id

\begin{abstract}
ABSTRAK
Pada umumnya kondisi air sungai yang ada di DKI Jakarta dari hulu menuju hilir semakin kurang baik kualitasnya baik kualitas fisik, kualitas kimia maupun kualitas biologi. Berdasarkan Indeks Pencemar sungai, sungai-sungai di DKI Jakarta termasuk dalam kategori cemar sedang dan cemar berat. Hal ini perlunya mengkaji kualitas air agar tidak mencemarkan lingkungan. Pemantauan kualitas air sungai di analisis secara fisik,kimia dan biologi. Kondisi fisik dan kimia mempengaruhi makhluk biologis yang ada di perairan. Bioindikator adalah organisme hidup seperti tanaman, plankton, hewan, dan mikroba, yang digunakan untuk menyaring kesehatan ekosistem alami di lingkungan. Indicator biologi dapat memantau secara kontinyu dan merupakan petunjuk yang mudah untuk memantau terjadinya pencemaran. Plankton adalah organisme perairan yang hidup melayang dengan pergerakan pasif dan tidak dapat melawan arus. Plankton yang mempunyai sifat selalu bergerak dapat juga dijadikan indikator pencemaran perairan. Plankton akan bergerak mencari tempat yang sesuai dengan hidupnya apabila terjadi pencemaran yang mengubah kondisi tempat hidupnya. Dengan demikian terjadi perubahan susunan komunitas organisme di suatu perairan di mana hal ini dapat dijadikan sebagai petunjuk terjadinya pencemaran di perairan. kesehatan perairan paling baik dicerminkan oleh plankton, yang bertindak sebagai sinyal peringatan dini.Tujuan dari penulisan ini adalah untuk mengetahui kualitas air sungai terhadap aktivitas masyarakat yang berada di sekitaran bantaran sungai. Dalam ulasan ini penulis mencoba menjelaskan konsep di balik Bioindikator dan plankton, dengan penekanan khusus pada potensi mereka untuk digunakan sebagai Bioindikator untuk penilaian kualitas air dan hasil yang berkaitan dengan hal ini. Metodologi yang digunakan ini adalah survey lapangan, observasi, dan analisis laboratorium.
\end{abstract}

Kata Kunci: sungai; kualitas air, bioindikator

\section{PENDAHULUAN}

Sungai merupakan sebuah aliran air yang sumber utamanya berasal dari alam, yang mengalir dari tempat yang tinggi ke tempat yang lebih rendah atau pendek dan kemudian bermuara ke danau, laut atau sungai yang keadannya lebih besar. Sungai merupakan salah satu ekosistem lotik (perairan mengalir) memiliki fungsi sebagai tempat hidup organisme (Maryono, 2005). Organisme yang hidup di dalam perairan sungai adalah organisme yang telah memiliki kemampuan untuk beradaptasi terhadap kecepatan arus (Susanto dan Rochidanto, 2008).

Pemantauan kualitas lingkungan terhadap sungai perlu dilakukan untuk melihat apakah terjadi dampak dengan melihat jenis dan besarnya dampak sebagai bahan evaluasi para pengambil keputusan untuk pencegahan dan penanggulangan dampak negatif (Fachrul, 2007). Salah satu aspek yang dapat digunakan untuk memantau kualitas lingkungan sungai yaitu bioindikator. Bioindikator sangat penting untuk memperlihatkan adanya keterkaitan antara faktor biotik dan abiotik suatu lingkungan. Bioindikator atau indikator ekologis merupakan suatu kelompok organisme yang hidup dan rentan terhadap perubahan lingkungan sebagai akibat dari aktivitas manusia dan kerusakan secara alami (Sumenge, 2008). Penulisan ini bertujuan untuk menentukan kualitas air sungai terhadap aktivitas warga yang tinggal di sekitar bantaran Kali. 


\section{TINJAUAN PUSTAKA}

\section{Kualitas air}

Kualitas air adalah kondisi kalitatif air yang diukur dan atau di uji berdasarkan parameter-parameter tertentu dan metode tertentu berdasarkan peraturan perundangundangan yang berlaku Pasal 1 Keputusan Menteri Negara Lingkungan Hidup Nomor 115 tahun 2003. Kualitas air dapat dinyatakan dengan parameter kualitas air. Parameter ini meliuti parameter fisik, kimia dan mikrobiologis

Menurut Jiao Ding et al. (2015) dalam jurnal Dawud (2016), Penurunan kualitas air merupakan akibat dan aktivitas manusia yang tidak peduli terhadap lingkungan dan tidak mengindahkan kaidah pembangunan berkelanjutan. Pencemaran Air adalah masuknya atau dimasukkannya makhluk hidup, zat, energi dan atau komponen lain ke dalam air oleh kegiatan manusia, sehingga kualitas air turun sampai ke tingkat tertentu yang menyebabkan air tidakdapat berfungsi sesuai dengan peruntukannya (PP No. 82 Tahun 2001).

\section{Bioindikator}

Bioindikator berasal dari dua kata yaitu bio dan indicator, bio artinya mahluk hidup seperti hewan, tumbuhan dan mikroba. Sedangkan indicator artinya variable yang dapat digunakan untuk mengevaluasi keadaan atau status dan memungkinkan dilakukannya pengukuran terhadap perubahan-perubahan yang terjadi dari waktu ke waktu. jadi bioindikator adalah komponen biotik (mahluk hidup) yang dijadikan sebagai indikator. Bioindikator juga merupakan indikator biotis yang dapat menunjukkan waktu dan lokasi, kondisi alam (bencana alam), serta perubahan kualitas lingkungan yang telah terjadi karena aktifitas manusia.

Bioindikator yang terjadi secara alami digunakan untuk menilai kesehatan lingkungan dan juga merupakan alat penting untuk mendeteksi perubahan dalam lingkungan, baik positif maupun negatif, dan dampak selanjutnya pada masyarakat manusia. Ada faktor-faktor tertentu yang mengatur keberadaan Bioindikator di lingkungan seperti transmisi cahaya, air, suhu, dan padatan tersuspensi. Melalui penerapan Bioindikator kita dapat memprediksi keadaan alami suatu wilayah tertentu atau tingkat / tingkat kontaminasi (Khatri \& Tyagi 2015)

Bioindikator dapat dibagi menjadi dua, yaitu bioindikator pasif dan bioindikator aktif. Bioindikator pasif adalah suatu spesies organisme, penghuni asli di suatu habitat, yang mampu menunjukkan adanya perubahan yang dapat diukur (misalnya perilaku, kematian, morfologi) pada lingkungan yang berubah di biotop (detektor). Bioindikator aktif adalah suatu spesies organisme yang memiliki sensitivitas tinggi terhadap polutan, yang mana spesies organisme ini umumnya diintroduksikan ke suatu habitat untuk mengetahui dan memberi peringatan dini terjadinya polusi.

Menurut Nobel dalam Kovacs (1992), indikator biologi dapat diklasifikasikan sebagai berikut :

1. Spesies indikator: kehadiran atau ketidakhadirannya mengindikasikan terjadi perubahan di lingkungan tersebut. mempunyai toleransi yang rendah terhadap perubahan lingkungan (stenoecious), bila kehadiran, distribusi serta kelimpahannya tinggi, maka spesies tersebut merupakan indikator positif. Sebaliknya, ketidakhadiran atau hilangnya suatu spesies karena perubahan lingkungannya, disebut indikator negatif.

2. Spesies monitoring: mengindikasikan terdapatnya polutan di lingkungan baik kuantitas maupun kualitasnya. Monitoring sensitif, sangat rentan terhadap berbagai polutan, sangat cocok untuk menunjukkan kondisi yang akut dan kronis. Monitoring akumulating, merupakan spesies yang resisten dan dapat mengakumulasi polutan dalam jumlah besar 
ke dalam jaringannya, tanpa membahayakan kehidupannya. Monitoring akumulating dapat berupa indikator pasif, yaitu spesies yang secara alami terdapat di lingkungan yang terpolusi, serta indikator aktif (eksperimental), yaitu spesies yang sengaja dibawa dari lingkungan alami yang tidak terpolusi ke lingkungan yang terpolusi (transplantasi).

3. Spesies uji, adalah spesies yang dipakai untuk mengetahui pengaruh polutan tertentu, sehingga sangat cocok untuk studi toksikologi.

Beberapa kriteria untuk menggunakan organisme sebagai bioindikator adalah :

1. Secara taksonomi telah stabil dan cukup diketahui.

2. Sejarah alamiah diketahui.

3. Siap dan mudah disurvei dan dimanipulasi.

4. Taksa yang lebih tinggi terdistribusi secara luas pada berbagai tipe habitat.

5. Taksa yang lebih rendah spesialis dan sensitif terhadap perubahan habitat.

6. Pola keanekaragaman mengambarkan atau terkait dengan taksa lainnya yang berkerabat atau tidak.

7. Memiliki potensi ekonomi yang penting.

\section{Fitoplankton}

Plankton berasal dari kata Yunani yaitu pengembara. Plankton merupakan organisme (tumbuhan atau hewan yang hidup bebas melayang-layang, terapung di dalam air yang kemampuan gerak terbatas sehingga mudah dibawa arus. Plankton terdiri dari dua kelompok yaitu fitoplankton dan zooplankton. Fitoplankton merupakan tumbuhan yang dapat berfotosintesis dan berperan sebagai produsen di perairan. Sedangkan zooplankton merupakan hewan dan sebagai konsumen pertama (Fajri,2013)

Fitoplankton adalah organisme pertama yang akan tergganggu oleh masuknya beban pencemar di perairan. Hal ini disebabkan karena fitoplankton merupakan organisme yang langsung memanfaatkan beban pencemaran tersebut. Oleh sebab itu, perubahan yang ada di perairan disebabkan akibat dari adanya masukkan yang menyebabkan kelimpahan, komposisi dan komunitas fitoplankton. Oleh karena itu fitoplankton dijadikan sebagai bioindikator perairan karena sifat hidupnya relatif menetap dengan jangka hidup yang relative panjang dan mempunyai toleransi spesifik pada lingkungan (Apridayanti, 2008).

Fitoplankton di perairan dapat memberikan informasi mengenai perairan tersebut. Fitoplankton digunakan sebagai indikator untuk mengevaluasi kualitas perairan dan tingkat kesuburan, dan mengetahui jenis-jenis fitoplankton yang mendominasi (Melati dkk, 2005).

Menurut Basmi (1995) Plankton dapat dikelompokkan berdasarkan beberapa hal yaitu:

a. Nutrient pokok :

1) Fitoplankton adalah plankton nabati ( $>90 \%$ dari alga) yang mengandung klorofil yang mampu mensitesa nutrisi anorganik menjadi zat organik melalui proses fotosintesis dengan energi yang berasal dari sinar matahari.

2) Saproplankton, adalah kelompok tumbuhan (bakteri dan jamur) yang tidak memiliki pigmen fotosintesis dan memperoleh nutrisi dan energi dari sisa organisme lain yang telah mati.

3) Zooplankton, adalah plankton hewani yang makanannya tergantung pada organismeorganisme lain yang masih hidup maupun partikel sisa organisme seperti detritus, selain itu plankton mengkonsumsi fitoplankton.

b. Berdasarkan lingkungan hidupnya terdiri atas :

1) Limnoplankton, adalah plankton yang hidup di air tawar.

2) Haliplankton, adalah plankton yang hidup di laut.

3) Hipalmyroplankton adalah plankton yang hidup di air payau. 
4) Plankton yaitu plankton yang hidupnya di kolam.

c. Berdasarkan sinar ditempat plankton hidup terdiri atas:

1) Hipoplankton adalah plankton yang hidupnya di zona afotik.

2) Epiplankton adalah plankton yang hidupnya di zona eufotik.

3) Bathiplankton adalah plankton yang hidupnya dekat dasar perairan yang umumnya tanpa sinar.

d. Berdasarkan asal usul plankton, dimana ada plankton yang hidup dan berkembang dari perairan itu sendiri dan ada yang berasal dari luar yaitu terdiri atas:

1) Autogenik plankton merupakan plankton yang berasal dari perairan itu sendiri.

2) Allogenik plankton merupakan plankton yang datang dari perairan lain.

Nybakken (1992), Menyatakan bahwa plankton dapat digolongkan berdasarkan ukuran. Penggolongan ini tidak membedakan antara fitoplankton dan zooplankton. Golongan plankton ini terdiri atas :

a. Megaplankton, merupakan plankton yang berukuran $2.0 \mathrm{~mm}$

b. Makroplankton, merupakan plankton yang berukuran $0.2-2.0 \mathrm{~mm}$

c. Mikroplankton, merupakan plankton yang berukuran $20 \mu \mathrm{m}-0.2 \mathrm{~mm}$

d. Nanoplankton, merupakan plankton yang berukuran $2 \mu \mathrm{m}-20 \mu \mathrm{m}$

e. Ultraplankton, merupakan plankton yang berukuran kurang dari $2 \mu \mathrm{m}$

Nanoplankton dan ultra plankton tidak dapat ditangkap menggunakan plankton net tetapi menggunakan sentrifuge atau dengan filter milipor.

Kelimpahan plankton dipengaruhi oleh perubahan kondisi lingkungan perairan. Salah satu faktor yang dapat mempengaruhi kelimpahan plankton adalah ketersediaan nutrisi, khususnya nitrogen sangat menentukan kelimpahan jenis fitoplankton di suatu perairan. Unsur nutrisi berupa nitrogen dan fosfor yang terakumulasi dalam suatu perairan akan menyebakan terjadinya kelimpahan fitoplankton. Sedangkan kelimpahan zooplankton yang tinggi menyebabkan rantai makanan di suatu perairan semakin kompleks.

Berdasarkan ekologisnya, plankton dibagi menjadi dua bagian yaitu plankton laut (haliplankton) dan plankton air tawar (limnoplankton) yang tinggal di perairan - perairan darat seperti sungai dan danau. Berdasarkan kedalaman plankton juga dibedakan menjadi beberapa kelompok sebagai berikut

a) Pleuston, merupakan biota di permukaan air laut,dimana selalu berhubungan dengan udara. Pergerakan biota ini dipengaruhi oleh angin. Contohnya :Physalia dan Velella

b) Neuston, adalah biota plankton yang tinggal pada lapisan permukaan dari kedalaman sampai dengan $10 \mathrm{~mm}$

c) Epipelagic Plankton, merupakan biota yang menempati lapisan perairan kedalaman $300 \mathrm{~m}$

d) Mesopelagic plankton, merupakan biota yang menempati lapisan perairan diantara 300- $1000 \mathrm{~m}$

e) Bathypelagic Plankton, merupakan biota yang menempati lapisan perairan antara $1000 \mathrm{~m}$ sampai dengan 3000-4000 m

f) Abyssopelagic plankton, merupakan biota yang menempati lapisan perairan lebih dari $3000-$ $4000 \mathrm{~m}$

g) Epibentic Plankton merupakan biota yang menempati lapisan perairan mendekati dasar atau secara temporer berkaitan dengan lapisan permukaan dasar.

\section{Faktor lingkungan yang mempengaruhi kehidupan fitoplankton}

Jumlah kelimpahan fitoplankton dipengaruhi oleh curah hujan dan arus. Curah hujan akan menyebabkan terjadinya pengenceran air dan penurunan salinitas dan serta meningkatkan masukan unsur hara dari daratan yang terbawa oleh luapan air di sungai. Pada musim hujan kelimpahan plankton cenderung tinggi dan melimpah.

Keberadaan organisme di perairan dipengaruhi oleh sifat fisika perairan yang terdiri dari kecepatan arus, suhu, kecerahan dan kedalaman serta sifat kimia perairan terdiri dari derajat 
keasaman (pH), Oksigen Terlarut (DO), Biological Oxigen Demand (BOD) dan Chemical Oxigen Demand (COD). Faktor lingkungan yang memegang peranan penting untuk penyebaran Polychaeta sangat banyak yang pada umumnya adalah faktor abiotik yaitu : kecerahan dan kedalaman, ubstrat perairan, suhu, salinitas, derajat keasaman, kandungan oksigen terlarut (DO), bahan organik, BOD, COD serta sebagian faktor biotik terdiri persediaan makanan dan komposisi jenis dari suatu komunitas (Reish 1979). Suhu air juga termasuk mempengaruhi kehidupan biota air karna dapat mempengaruhi jumlah oksigen terlarut,dan dapat menyebabkan kematian hewan air (Fachrul,2011)

Kualitas perairan sungai yang digunakan dalam penelitian kualitas air di kupang Chlorophyceae 15 genera, Cyanophyceae 8 genera, dan Bacillariophyceae 19 genera. berdasarkan tersebut kualitas air sungai di kupang masih bagus. Pada penelitian lain di Lombok utara Kelimpahan dan indeks ekologi zooplankton dipengaruhi oleh kondisi lingkungan (fisik-kimia) di perairan antara lain yaitu kecerahan, $\mathrm{pH}$ dan oksigen terlarut. Kelimpahan fitoplankton dapat diakibatkan oleh tingginya kandungan nitrat, fosfat dan POM. Pada Kali Krukut segmen tengah biota Macrozoobentos terdapat 23 spesies diantaranya 9 kelas 3 tipe Bivalves, 7 tipe of Arthopoda, 2 types of Molusca, 4 tipe dari Insects, 4 tipe dari Oligochaeta, 2 types of Malacostraca, 1 Crustacea, 1 Diptera, dan 1 Nematodes.

\section{PENUTUP}

Kualitas air dapat menggunakan fitoplankton sebagai bioindikator kualitas air, dimana fitoplankton merupakan biota yang sangat respon terhadap pencemaran air dan mempunyai toleransi spesifik terhadap lingkungan dan juga jangka hidup plankton relative panjang

\section{DAFTAR PUSTAKA}

Apridayanti, E. (2008) : Evaluasi Pengelolaan Lingkungan Perairan Waduk Lahor Kabupaten Malang Jawa Timur, Tesis Universitas Diponegoro, Semarang.

Basmi. 1995. Planktonologi : Organisme Penyusun Plankton, Klasifikasi dan Terminologi, Hubungan antara Fitoplankton dan Zooplankton, Siklus Produksi umumnya di Perairan. Fakultas Perikanan IPB, Bogor. 23-25 hlm.

Dawud, Muhammad dkk. 2016. Analisis Sistem Pengendalian Pencemaran Air Sungai Cisadane Kota Tangerang Berbasis Masyarakat.

F.A.,Bonecker, C.C., 2013. Floods control the influence of environmental gradients on the diversity of zooplankton communities in a neotropical floodplain. Aquat. Sci. 75, 607-617.

DOI: https://doi.org/10.1007/s00027-013-0304-9.

Fachrul, Melati Ferianita. 2007. Metode Sampling Bioekologi. Bumi Aksara. Jakarta

Fachrul, M.F.Diana hendrawan. Fredy Prasetyo. 2011. Kajian Laju Pemurnian Sungai Cipinang Bagian Hulu Berdasarkan Parameter DO dan BOD. Indonesian Journal of Urban and Environmental Technology. 5(6):218

DOI: http://dx.doi.org/10.25105/urbanenvirotech.v5i5.691

Griselda, Chaparro. et al. 2019.Multi-scale analysis of functional plankton diversity in floodplain wetlands: Effects of river regulation. Science of the Total Environment. DOI: https://doi.org/10.1016/j.scitotenv.2019.02.147

Junaidi, Muhammad., Nurliah1 , F.Azhar.2018. Struktur Komunitas Zooplankton di Perairan Kabupaten Lombok Utara, Provinsi Nusa Tenggara Barat. Jurnal Biologi Tropis. 18(2): 167

DOI: http://dx.doi.org/10.29303/jbt.v18i2.800 
Khatri N, Tyagi S. 2015. Influences of natural and anthropogenic factors on surface and groundwater quality in rural and urban areas. Front Life Sci. 8(1):23-39.

DOI: $10.1080 / 21553769.2014 .933716$

Lorenzen, C.J., 1967. Determination of chlorophyll and phaeo-pigments: spectrophotometric equations. Limnol. Oceanog. 12, 343-346. DOI: https://doi.org/10.4319/1o.1967.12.2.0343.

Melati Ferianita-Fachrul,Herman Haeruman, Leistari C.Sitepu. 2005. Komunitas fitoplankton sebagai Bio-indikator kualitas perairan Teluk Jakarta.Dalam: seminar nasional MIPA .Universitas Indonesia.Depok, 24-26 November 2005.

Nybakken, J. W. 1992. Biologi Laut Suatu Pendekatan Biologis. PT Gramedia. Jakarta

Peraturan Pemerintah Republik Indonesia Nomor 82 Tahun 2001, Tentang Pengelolaan Kualitas Air dan Pengendalian Pencemaran Air. Lembaran Negara Republik Indonesia Tahun 2001 Nomor 153.

Pourafrasyabi, M., Z. Ramezanpour. 2014. Phytoplankton as bio-indicator of water quality in Sefid Rud River - Iran (South Caspian Sea). Caspian Journal of Environmental Sciences. 12(1):38

Reckendorfer,W., Funk, A., Gschöpf, C., Hein, T., Schiemer, F., Arnott, S., 2013. Aquatic ecosystem functions of an isolated floodplain and their implications for flood retention and management. J. Appl. Ecol. 50, 119-128.

DOI: https://doi.org/10.1111/1365- 2664.12029.

Reish, D.J. 1979. I C. W. Hart., and Samuel L. H. F. (eds. 2). Academic Press, New York. pp 77-121.

Schagerl, M., Drozdowski, I., Angeler, D., Hein, T., Preiner, S., 2009. Water age - a major factor controlling phytoplankton community structure in a reconnected dynamic floodplain (Danube, Regelsbrunn, Austria). J. Limnol. 68, 274-287.

DOI: https://doi.org/10.3274/JL09-68-2-11.

Simões, N.R., Deo Dias, J., Leal, C.M., de Souza MagalhãesBraghin, L., Lansac-Tôha, Sun W, Xia CY, Xu MY, Guo J, Wang AJ, Sun GP. Distribution and abun-dance of archaeal and bacterial ammonia oxidizers in the sediments of theDongjiang River, a drinking water supply for Hong Kong. Microb Environ 2013., DOI: http://dx.doi.org/10.1264/jsme2.ME13066.

Sumenge, V. 2008. Penentuan Kualitas Air Sungai Sendangan Kakas Dengan Bioindikator Keanekaragaman Serangga Air. [Skripsi]. Universitas Samratulangi, Manado.

Sun W, Xia CY, Xu MY, Guo J, Wang AJ, Sun GP. 2013.Distribution and abun-dance of archaeal and bacterial ammonia oxidizers in the sediments of theDongjiang River, a drinking water supply for Hong Kong. Microb Environ., DOI: http://dx.doi.org/10.1264/jsme2.ME13066.

Susanto, H. dan A. Rochdianto. 2008. Kiat Budi Daya Ikan Mas Dilahan Kritis. Penebar Swadaya Depok. Jakarta. 